\title{
Identifying Factors that Affect Consumer's Satisfaction at Parklatz Café in Ponorogo City, East Java, Indonesia: An Application of Exploratory Factor Analysis
}

\author{
Adib Susilo $^{1 *}$ \\ ${ }^{1}$ Department of Bussiness Administration, \\ Kulliyah of Economics and Management Sciences, \\ International Islamic University of Malaysia \\ Jalan Gombak, 53100, Selangor, Malaysia \\ *adib.susilo27@gmail.com
}

DOI: https://doi.org/10.22219/jes.v5i1.11399

Check for updates

\begin{tabular}{ll}
\hline & \multicolumn{1}{c}{ ABSTRACT } \\
\cline { 2 - 2 } $\begin{array}{l}\text { Keywords: } \\
\text { Consumer }\end{array}$ Thavior; & This research aims to find the factors that affect consumer's satisfaction at \\
satisfaction; & at Parklatz Café in Ponorogo City, East Java, Indonesia. This research is \\
customer & quantitatif using a survey of 124 respondents. The respondents were asked \\
satisfaction; & to give their responses on a five-point Likert scale through a questionnaire. \\
service. & $\begin{array}{l}\text { The data analyzed with exploratory factor analysis (EFA) using Varimax } \\
\text { rotation, which reduced the data into several factors. The findings of this }\end{array}$ \\
& $\begin{array}{l}\text { study indicate that product, service satisfaction, price satisfaction, } \\
\text { promotion, and customer hospitality influence customer satisfaction of } \\
\text { Parklatz Café in Ponorogo City. }\end{array}$ \\
\hline
\end{tabular}

Article Info:

Submitted:

01/1/2020

Revised:

10/02/2020

Published:

27/02/2020

How to cite: Susilo, A. (2020). Identifying Factors that Affect Consumer's Satisfaction at Parklatz Café in Ponorogo City, East Java, Indonesia: An Application of Exploratory Factor Analysis. Falah: Jurnal Ekonomi Syariah, 5(1), 1-14. https://doi.org/10.22219/jes.v5i1.11399 


\section{INTRODUCTION}

Food industry especially cafe and bar sector rose significantly in 2012 and 2013. In America the business grew to 10,631 Unit in 2013 or $2.4 \%$ since 2003. In addition, GDP growth in this sector reaches about 2,648 Million in 2012, or 1.7\% rose from 2002 to 2012 (Connor \& Whiteford, 2014).

Consumer satisfaction may refer to personal perception of product or services or might be performance in relation to his expectation (Sit, et. al., 2009). In highly competitive business environment, consumer satisfaction gave a huge play role and impact to the company. The company will produce a high quality product and improve their quality of product in order to reach the brand image to their consumer (TorresMoraga, Vasquez-Paraga, Zamora-Gonzales, 2008).

The more quality the product, the more loyalty the company gain from the consumer. The consumer loyalty would spread from consumer after consumer by the word of mouth power (Tsai, Lin, Li, 2014; Oh \& Kim, 2017). Indeed, the modern word of mouth power supported by social media such as Instagram, Twitter, Facebook, even personal messages on chat app such as Whatsapp or Telegram and the oldest one BBM. Therefore, the brand image of a product should be built from the valuable identity or symbolic meaning (Anisimova, 2016). In other word the costumer will felt their own value of the experiences they tried (Heri, 2017). This is also part of consumer or costumer services which lead to their satisfaction and loyalty to the company (Fraering \& Minor, 2013). To achieve the consumer satisfaction company need to provide all services so the costumer felt the superior value (Kriswandari, 2017).

In other word, hospitality could be improved in other field of services. Such as Financial services in Bank prosperity services in restaurant or cafe (Oh \& Kim, 2017; Awan, Bukhari, Iqbal, 2011; Qin \& Prybutok, 2009; Andaleeb \& Conway, 2006), comfort services in beauty salon or beauty services it-self (Sachdev \& Verma, 2004), even in educational services it would be improved (Kriswandari, 2011). Indeed, product quality (Kurniati, Silvia, Efendi, 2016) which built brand image (Winarno, 2010) with a symbolic value and the services that the company gave (Anisimova, 2016; Sachdev \& Verma, 2004) would affect the price of the product (Kaura, Prasad, Sharma, 2015).

Many studies have attempted to propose some factors that affect customer's satisfaction. Maritn-Consugera, Molina, Esteban, (2007) stated that price is the factor that influence the income or inflow of resources. Therefore, pricing decision is a need in a company that affect to the loyalty of consumer or costumer if the company or the manager understood how the consumer and costumer respond to the price changes (Nazari, Hosseini, Tabatabaie, 2014; Malik, Ghafoor, Hafiz, 2012). The price defined as what is given up or sacrificed to obtain a product or service (Razak, Nirwanto, Triatmanto, 2016). The price also suggested by Kotler and Armstrong (2012) as the 
amount of money charged for a product or a service or the sum of the values that customers exchange for the benefits of having or using a product or service.

Furthermore, Razak, Nirwanto, Triatmanto (2016) stated that customer perceived a certain price, which the high-low of the price of a product could significantly affected consumer intention to purchase a product. On the other hand, the price of food in the item menu could greatly influence the customer perception (Razak, Nirwanto, Triatmanto, 2016). Wheather the product is high-cost or low-cost, as long as it meets the consumer expectation, it always came with good perception to the company. Indeed, fairness of price would lead to better perception of the product and the company (Malik, Ghafoor, Hafiz, 2012). According to Hermann, et.al (2007), price fairness was influenced by procedural and distributive consideration. Whereas the fairness of perceived price is playing significant role in decision making in order to balance the consumer price perception (Kaura, Prasad, Sharma, 2015).

On the other hand, promotion has it own role to the product and the successful of selling it (Park \& Lennon, 2009). Although, promotion became the last thing thought by the company, it could affect a lot to the price of product, and indeed, to the consumer decision whether to purchase it or not (Honea \& Dahl, 2005). Stimulating interest to the brand, creating positive brand attitude, showing how the product could satisfy consumer wants, needs and desire, can be define as promotion goals (Graeff, 1995). The type of promotion could be categorized in form of price-based promotion (Walters \& Bommer, 1996) and non-price-based promotion (Parson, 2003).

Rowley (1998) stated that tools of promotion consist of some tools such: advertising, direct marketing, sales promotions, public relations and publicity, personal selling, and sponsorship. Osman, Fah \& Foon (2011) stated that promotion is the techniques to attract the consumer or customer to purchase more or to try a product or service. Promotion also can be defined as marketing and communication activities that could change the price-value relationship of product or service that perceived by target (Andreti, et, al., 2013). Furthermore, the tools of promotion for food or cafe is product promotion (Carlson, 2018) such as extra product and extra volume (Smith \& Sinha, 2000), sales promotion (Santini, et, al., 2015) such as Card sales (Schultz \& Block, 2014), coupons, discount day, price adjustment, and display (Schultz \& Peltier, 2013).

However, there have been no previous studies that have conducted research related to customer satisfaction in relation to the use of exploratory factor analysis. This paper presents to analyze the practice of Exploratory Factor Analysis (EFA) in a research which works to identify the relationship between factors. This paper aimed to peroform in how EFA conducted which can be used in the several research, where the factors need to be grouping and then confirmed to assess the degree to which the data meet the expected structure. 


\section{RESEARCH METHOD}

The data for this study were collected from the customer of Parklatz cafe through questionnaire survey method. The customer of Parklatz cafe largely are student of university, lecturer, and some are local community around the university. The average customer of Parklatz cafe per day is around 30 persons. The most customer visits to Parklatz cafe in every weekend, where the football match was exhibited on a large screen to watch together. The number of visitors increased to 60 to 100 persons on weekend. Therefore, based on the average consumer that visiting to the Parklatz cafe, researcher asks to 200 consumers of Parklatz café to respond. At the end, total 124 respondents were received to be analysed.

Parklatz cafe located at the only one biggest International University at Ponorogo, with thousand potentials consumers and customers. With one uniqueness most of the consumer is male gender which stay around the university area. Related to this, consumer or customer satisfaction can be influenced by many factors depend on the situation and the background of the company of the café and bar sector. Therefore, it is important to know the determinant factors of consumer or customer satisfaction of in Parklatz Café in Ponorogo City in order the owners could determine an exact decision in managing their strategies.

The respondents consisted of $92.7 \%$ male and $7.3 \%$ female. Majority of respondent were student of university with a percentage of about $67.2 \%$, followed by lecturer of university around $22.1 \%$, university staff $5 \%$, teachers of Madrasah between $2.5 \%$ and other occupation about $3.2 \%$. Mostly respondents about $83.9 \%$ ever hang out to Parklatz café and purchase the food and beverages product of café, while $16.1 \%$ are never came to cafe or just heard about it. Specifically, about $16.1 \%$ were regular customer and around $22.6 \%$ were probably regular customer, while the rest of $61.3 \%$ respondents were irregular customer. Meanwhile, based on intensity of customer visiting, 110 visitors came less than 3 times in a week, 12 of them came around 4 to 6 times in a week and the rest of a total of $76.6 \%$ respondents aged 20-29 years old, $11.3 \%$ aged 30-39 years old, $10.5 \%$ aged less than 20 and 1,6\% aged 40-49 years old. Finally, a total of $36.1 \%$ respondents have 144 RM or bellow of income, while respondent with $145 \mathrm{RM}-430 \mathrm{RM}$ of income respectively reach $0.8 \%$ under the 144 RM or bellow of income, as $15.1 \%$ have income between $431 \mathrm{RM}$ to $718 \mathrm{RM}$, while the rest of about $13.4 \%$ respondent have income around $719 \mathrm{RM}$ and above. Details of entire respondents under this study are presented in table below. 
Vol. 5 No. 1 (2020)

ISSN (print): 2502-3918 | ISSN (online): 2502-7824

Table 1. Respondent's Profile

\begin{tabular}{|c|c|c|c|}
\hline No & Content & Frequency & Percentage \\
\hline \multirow[t]{3}{*}{1} & Gender & & \\
\hline & Male & 115 & $92.7 \%$ \\
\hline & Female & 9 & $7.3 \%$ \\
\hline \multirow[t]{6}{*}{2} & Occupation & & \\
\hline & Student of University & 83 & $67.2 \%$ \\
\hline & Lecturer of University & 28 & $22.1 \%$ \\
\hline & Staff of University & 6 & $5 \%$ \\
\hline & Teacher of Madrasah & 3 & $2.5 \%$ \\
\hline & Other Occupation & 4 & $3.2 \%$ \\
\hline \multirow[t]{3}{*}{3} & Visitor & & \\
\hline & Yes & 104 & $83.9 \%$ \\
\hline & Never & 20 & $16.1 \%$ \\
\hline \multirow[t]{4}{*}{4} & Potential Customer & & \\
\hline & Regular Customer & 20 & $16.1 \%$ \\
\hline & Probably Regular Customer & 28 & $22.6 \%$ \\
\hline & Irregular Customer & 76 & $61.3 \%$ \\
\hline \multirow[t]{4}{*}{5} & Visiting Intensity (in a week) & & \\
\hline & Less than 3 times & 110 & $88.7 \%$ \\
\hline & 4 to 6 times & 12 & $9.7 \%$ \\
\hline & More than 7 times & 2 & $1.6 \%$ \\
\hline \multirow[t]{5}{*}{6} & Age of customer (in yeras) & & \\
\hline & Bellow 20 & 13 & $10.5 \%$ \\
\hline & $20-29$ & 95 & $76.6 \%$ \\
\hline & 30-39 & 14 & $11.3 \%$ \\
\hline & $40-49$ & 2 & $1.6 \%$ \\
\hline \multirow[t]{5}{*}{7} & Income (in RM) & & \\
\hline & Bellow 144 & 45 & $36.1 \%$ \\
\hline & $145-430$ & 44 & $35.3 \%$ \\
\hline & $431-718$ & 19 & $15.1 \%$ \\
\hline & 719 or above & 16 & $13.4 \%$ \\
\hline
\end{tabular}

Meanwhile, to running the collected data from the respondent, twentytwo variables are composed based on the theoretical framework. The twenty two variables that allegedly influence the consumer satisfaction in Parklatz café Ponorogo presented on the table 2 below.

Table 2. Variables that allegedly influence the consumer satisfaction

\begin{tabular}{ll}
\hline $\mathbf{X}$ & \multicolumn{1}{c}{ Variables } \\
\hline 1 & Direct marketing \\
\hline 2 & Disseminating promotions through electronic media (adevertising) \\
\hline 3 & Sales promotion \\
\hline 4 & Fairness of food price \\
\hline 5 & Suitable price of food with the quality \\
\hline 6 & Fairness of beverages price \\
\hline 8 & Suitable price of beverages with the quality \\
\hline 9 & Product variety \\
\hline
\end{tabular}


ISSN (print): 2502-3918| ISSN (online): 2502-7824

\begin{tabular}{ll}
\hline & \\
\hline 10 & Product quality \\
\hline 11 & Featured product or brand image \\
\hline 13 & Product return services \\
\hline 14 & Empathy services of the café employee \\
\hline 15 & Compliment to costumer from the café staff and employee \\
\hline 16 & Free charge of wi-fi services \\
\hline 17 & Reliability of the café employee \\
\hline 18 & Delivery services of café \\
\hline 20 & Promotion satisfaction \\
\hline 21 & Price satisfactions \\
\hline 22 & Product satisfaction \\
\hline
\end{tabular}

Those twentytwo items in table 2 were converted to questionnaire and analysed using exploratory factor analysis (EFA). The principal component analysis with varimax rotation was applied. Keiser-Meyer-Olkin (KMO) score and Bartlett's test was verified (Hair, et, al., 2010). The adequacy of data to factor analysis is usually evaluates by Kaiser-Meyer-Olkin (KMO) Measure and Bartlett's test of sphericity. Kaiser (1974) had suggested that for KMO in the 0.90s adequacy is marvellous, in the $0.80 \mathrm{~s}$ is meritorious, in the $0.70 \mathrm{~s}$ is middling, in the $0.60 \mathrm{~s}$ is mediocre, in the $0.50 \mathrm{~s}$ is miserable and below 0.5 - unacceptable. The Bartlett's test of sphericity should be significant (po0.05). Following phase of factor analysis is the choice of number of factors. The most popular criteria are: "Kaiser rule - retain only those factors with an eigenvalue larger than 1; and Cattell criterion - a scree-plot".

The extraction of factors is usually conducted by principal components analysis (PCA). Principal component analysis is usually used in typical EFA - it is one of the techniques used for calculation of factor loadings. PCA is used as the adaptation of classical Hotteling's principle components analysis for factor analysis, and in practically is the most popular. The next step of factor analysis is the choice of rotation method. The goal of rotation is to simplify and clarify the data structure (Malina, 2004). On the basis of loadings values we could indicate the variables with practically importance - it should be above \pm 0.5 . The analysis could be finished by interpretation of factors, using loading for all variables).

\section{RESULT AND DISCUSSION}

The result of this study indicated that, there are four factors emerged after analysis data, namely, product services, price satisfaction, promotion, customer hospitality. The examination method of KMO that used to measure sampling adequacy suggested that the sample was factorable where about 0.898, and Bartlett's test of sphericity scored 1980.484 with significant level of 0.000 less than 0.05 , which means there are correlations between variables. Table below shows KMO and Bartlett's test. 
Table 3. KMO and Bartlett's Test

\begin{tabular}{lll}
\hline \multicolumn{2}{c}{ Kaiser-Meyer-Olkin Measure of Sampling Adequacy. } & .898 \\
\hline \multirow{2}{*}{ Bartlett's Test of Sphericity } & Approx. Chi-Square & 1980.458 \\
\cline { 2 - 3 } & df & 231 \\
\cline { 2 - 3 } & Sig. & .000 \\
\hline
\end{tabular}

Based on principal component analysis illustrate each variable extraction value. For example, extraction value of variable X1 is 0.692 which mean that about $69.2 \%$ of variance can be explained by the form of X1 variable factors. Meanwhile, 0.775 is the amount of X2 variable extraction, which indicates that $77.5 \%$ of variance can be explained by the form of X2 variable factors. In line with previous variables, extraction value of variable $\mathrm{X} 3$ is 0.768 which mean that about $76.8 \%$ of variance can be explained by the form of X3 variable factors. Meanwhile, 0.771 is the amount of X4 variable extraction, which indicates that $77.1 \%$ of variance can be explained by the form of X4 variable factors.

Another variable example, extraction value of variable X5 is 0.846 which mean that about $84.6 \%$ of variance can be explained by the form of X5 variable factors. Meanwhile, 0.785 is the amount of X6 variable extraction, which indicates that $78.5 \%$ of variance can be explained by the form of X6 variable factors. In line with previous variables, extraction value of variable $\mathrm{X} 7$ is 0.830 which mean that about $83.0 \%$ of variance can be explained by the form of X7 variable factors. Meanwhile, 0.637 is the amount of X8 variable extraction, which indicates that $63.7 \%$ of variance can be explained by the form of $\mathrm{X} 8$ variable factors.

On the other hand, the rest extraction value has same explanation. For example, extraction of variable $\mathrm{X} 9$ is 0.628 which mean that about $62.8 \%$ of variance can be explained by the form of X9 variable factors. Meanwhile, 0.747 is the amount of X10 variable extraction, which indicates that $74.7 \%$ of variance can be explained by the form of X10 variable factors. In line with previous variables, extraction value of variable X11 is 0.587 which mean that about $58.7 \%$ of variance can be explained by the form of X11 variable factors. Meanwhile, 0.345 is the amount of X12 variable extraction, which indicates that $34.5 \%$ of variance can be explained by the form of X12 variable factors, and so on.

This research is research in the field of social science. The minimum value of cumulative percentage for social science research is $60 \%$. In this research, the percentage of $68.015 \%$ was obtained greater than $60 \%$, means that the formation of these seven factors has been considered valid and acceptable. According to Truong \& McColl (2011), factor loadings should be greater than 0.5 for better results. Meanwhile, table 9 illustrate that Factor I consist of X10, X7, X5, X8, X13, X4, X17, X6, X14, X11, 
X1, X9, X3, X22, X18, X21, X20, and X2. Factor II Consist X2 and X19, while factor III consist of X20 and X15. On the contrary, there is no variable entered into factor IV. Whereas, the eigenvalues and the scree plot showed that there are four factors. As well as the trend that appears on 2 variables and 2 factors that exist, X2 on factor II already appear in factor I and X20 on factor III already appear on factor I. Similar to the unique trend, there are two variables had no loading in all factors (X12 and X16).

On the other hand, based on Analysis of rotation method using varimax with kaiser normalization, can be seen that there are several changes due to the rotation method. But, there is still problem, namely cross-loading in the X7 (loaded in Factor I and III) and also X22 (loaded in Factor I and II). Indeed, there are still two variables not load to any factors. Therefore, X7, X22, X8 and X12 must be removed.

From Measures of sampling adequacy, can be seen that all variables have MSA $>0.50$. This means that data can be declared eligible and can be used for further analysis. Once the data is declared eligible for factor analysis, will be conducted the extraction process factors. Based on Principal Component Analysis the variable extraction value. For example, extraction value of variable $\mathrm{X} 1$ is 0.689 which mean that about $68.9 \%$ of variance can be explained by the form of X1 variable factors. Meanwhile, 0.749 is the amount of X2 variable extraction, which indicates that $74.9 \%$ of variance can be explained by the form of X2 variable factors. In line with previous variables, extraction value of variable $\mathrm{X} 3$ is 0.772 which mean that about $77.2 \%$ of variance can be explained by the form of X3 variable factors. Meanwhile, 0.778 is the amount of X4 variable extraction, which indicates that $77.8 \%$ of variance can be explained by the form of $\mathrm{X} 4$ variable factors.

Another variable example, extraction value of variable X5 is 0.810 which mean that about $81.0 \%$ of variance can be explained by the form of X5 variable factors. Meanwhile, 0.807 is the amount of X6 variable extraction, which indicates that $80.7 \%$ of variance can be explained by the form of X6 variable factors. In line with previous variables, extraction value of variable $\mathrm{X} 9$ is 0.641 which mean that about $64.1 \%$ of variance can be explained by the form of X9 variable factors. Meanwhile, 0.752 is the amount of X10 variable extraction, which indicates that $75.2 \%$ of variance can be explained by the form of X10 variable factors and so on.

Based on Table below, factor I (Product and Service Satisfaction) contributes with the highest percentage reach about 45, 87\%, followed by factor II (Price Satisfaction) with 10.0\%. Meanwhile, factor II (Promotion) and Factor IV (Customer Hospitality) have the percentage $8.61 \%$ and $6.19 \%$ respectively. All Factors had high percentage with $70.71 \%$ totally. 
Vol. 5 No. 1 (2020)

ISSN (print): 2502-3918 | ISSN (online): 2502-7824

Table 4. Result of Factor Analysis

\begin{tabular}{|c|c|c|}
\hline Factors & Measurement Items & Factor Loadings \\
\hline \multirow{7}{*}{$\begin{array}{c}\text { I } \\
\text { Product and Customer } \\
\text { Services }\end{array}$} & Empathy & 0.825 \\
\hline & Delivery Service & 0.761 \\
\hline & Reliability & 0.703 \\
\hline & Responsive & 0.673 \\
\hline & Brand Image & 0.628 \\
\hline & Product Quality & 0.612 \\
\hline & Favourable Product & 0.609 \\
\hline \multirow{5}{*}{$\begin{array}{c}\text { II } \\
\text { Price Satisfaction }\end{array}$} & Price Satisfaction & 0.836 \\
\hline & Drink Price Fairness & 0.787 \\
\hline & Food Quality & 0.739 \\
\hline & Food Price Fairness & 0.730 \\
\hline & Product Satisfaction & 0.657 \\
\hline \multirow{4}{*}{$\begin{array}{c}\text { III } \\
\text { Promotion }\end{array}$} & Advertising & 0.808 \\
\hline & Sales Promotion & 0.763 \\
\hline & Promotion Satisfaction & 0.728 \\
\hline & Direct Marketing & 0.638 \\
\hline \multirow{2}{*}{$\begin{array}{c}\text { IV } \\
\text { Customer Hospitality }\end{array}$} & Compliment to Customer & 0.777 \\
\hline & Free WiFi & 0.762 \\
\hline
\end{tabular}

In connection with sum up, from the table 4 shows that product services are the totality of features and characteristics of a product or service that bears on its ability to satisfy given needs, and it aim to gain higher profit from sold product and indeed to insure customer loyalty, build strong barrier against the competitor (Kanovska, 2010). Product and service quality, simultaneously affects the intention of customer to purchase a product, in this case, to purchase product and hangout at parklatz café, service of product and quality directly affects satisfaction and satisfaction directly affects the positive behavioural intentions (Jahanshahi, et, al., 2011).

On the other hand, Price satisfaction is a complex construct consisting of several dimensions, i.e. price-quality ratio, price fairness, price transparency, price reliability and relative price (Matzler, Wurtele \& Renzl, 2006). These dimensions constitute the determinants of price satisfaction, and consequently their satisfaction could affect to customer loyalty. Then, promotion is an action-focused marketing event whose purpose 
is to have a direct impact on the behaviour of the firm's customer in order to purchase the product or services (Blattberg \& Bresich, 2012). An effective promotion requires a good understanding of the process Power of persuasion and how this process affects Environmental factors (Alam, Almotairi \& Gaadar, 2013).

Finally, the customer hospitality that define as the design of structure of quality and customer services which focusing on location and facilities and directly linked to customer satisfaction and the development of customer loyalty (Kuhn, et, al., 2018). In this case, parklatz café were on of food industry which directly selling the product to the customer or consumer. Which mean, hospitality have had an essential part that contributes to satisfy the physiological needs and dining experiences of the customer or consumer (Kandampully, Zhang \& Jaakkola, 2017).

\section{CONCLUSION}

Based on the findings, there are four factors that can influence the consumer or customer satisfaction in Parklatz Café Ponorogo. Factor I (Product and Service Satisfaction) contributes with the highest percentage reach about 45, 87\%, followed by factor II (Price Satisfaction) with 10.0\%. Meanwhile, factor II (Promotion) and Factor IV (Customer Hospitality) have the percentage $8.61 \%$ and $6.19 \%$ respectively. All Factors had high percentage with $70.71 \%$ totally.

However further studies are needed to use a wider coverage of research sample and research object. The limitation of this study is that the scope of the research is only in consumer's satisfaction at at Parklatz Café in Ponorogo City, East Java, Indonesia costhe fintech.

\section{REFERENCES}

Alam, A., Almotairi, D. M., \& Gaadar, D. K. (2013). The Role of Promotion Strategies in Personal Selling. Far East Journal of Psychology and Business, 12(4), 41-49. Retrieved from http://www.fareastjournals.com/files/FEJPBV12N3P4.pdf

Andaleeb, S. \& Conway, C. (2006). Customer Satisfaction in the Restaurant Industry: An Examination of the Transaction-Specific Model. Journal of Services Marketing. 20(1), 3-11. https://doi.org/10.1108/08876040610646536

Andreti, J., et, al,. (2013). The Analysis of Product, Price, Place, Promotion and Service Quality on Customers' Buying Decision of Convenience Store: A Survey of Young Adult in Bekasi, West Java, Indonesia. International Journal of Advances in Management and Economics, 2(6), 72-78. Retreived from https://www.managementjournal.info/index.php/IJAME/article/view/332

Anisimova, T. (2016). The Effects of Corporate Brand Symbolism on Consumer Satisfaction and Loyalty: Evidence from Australia. Asia Pacific Journal of Marketing and Logistics, 28(3), 481-498. https://doi.org/10.1108/APJML-052015-0086 
Vol. 5 No. 1 (2020)

ISSN (print): 2502-3918 | ISSN (online): 2502-7824

Awan, H. M., Bukhari, K. S. \& Iqbal, A. (2011). Service Quality and Customer Satisfaction in the Banking Sector: A Comparative Study of Conventional and Islamic Banks in Pakistan. Journal of Islamic Marketing, 2(3), 203-224. https://doi.org/10.1108/17590831111164750

Blattberg, R. \& Briesch, R. (2012). Sales Promotions. The Oxford Handbook of Pricing Management. doi: 10.1093/oxfordhb/9780199543175.013.0024. Retreived from

https://www.oxfordhandbooks.com/view/10.1093/oxfordhb/9780199543175.001 .0001/oxfordhb-9780199543175-e-24

BPS-Statistics of Ponorogo Regency. (2017). Ponorogo Regency in Figures 2017. Ponorogo: BPS-Statistics of Ponorogo Regency. Retrieved from https://ponorogokab.bps.go.id/

Carlson, J. P., (2018). Consumer Evaluations of Bonus Packs Offered With Price Discounts. Journal of Consumer Marketing, (35)1, 22-31. https://doi.org/10.1108/JCM-09-2015-1555

Connor, J. \& Whiteford, A. (2014), a Profile of the Cafés, Bars and Restaurants Sectors. Infometric. $\quad$ Service $\quad$ IQ. $\quad$ Retrieved from https://www.serviceiq.org.nz/assets/Uploads/Food-Services.pdf

Fraering, M., \& Minor, M. S., (2013). Beyond Loyalty: Customer Satisfaction, Loyalty, and Fortitude. Journal of Services Marketing, 27(4), 334-344. https://doi.org/10.1108/08876041311330807

Hair, J.F., Black, W.C., Babin, B.J. \& Anderson, R.E. (2010). Multivariate Data Analysis. $7^{\text {th }}$ Edition. New York: Pearson.

Heri, Helwen. (2017). Analysis the Effect of Service Quality, Customers Value, Customer Satisfaction and Customer Trust on Corporate Image. IOSR Journal of Business and Management, 19(6), 38-46. doi: 10.9790/487X-1906013846 Retrieved from http://www.iosrjournals.org/iosr-jbm/papers/Vol19issue6/Version-1/F1906013846.pdf

Herrmann, A., Xia, L., Kent, M. B., \& Huber, F. (2007). The influence of price fairness on customer satisfaction: An empirical test in the context of automobile purchases. Journal of Product and Brand Management, 16(1), 49-58. https://doi.org/10.1108/10610420710731151

Honea, H. \& Dahl, D. W. (2005). The Promotion Affect Scale: Defining the Affective Dimensions of Promotion. Journal of Business Research, 58(4), 543-551. https://doi.org/10.1016/S0148-2963(03)00145-0

Jahanshahi, A. et, al. (2011). Study the Effects of Customer Service and Product Quality on Customer Satisfaction and Loyalty. International Journal of Humanities and Social Science, 1(7), 253-260. Retreived from http://www.ijhssnet.com/journals/Vol._1_No._7_[Special_Issue_June_2011]/33. pdf

Kaiser, H.F. (1974). An Index of Factorial Simplicity. Psychometrika. 39(1), 31-36. https://doi.org/10.1007/BF02291575

Kandampully, J., Zhang, T. \& Jaakkola, E. (2017). Customer Experience Management in Hospitality: A Literature Synthesis, New Understanding, and Research 
Agenda. International Journal of Contemporary Hospitality Management, 30(1), 21-56. https://doi.org/10.1108/IJCHM-10-2015-0549

Kaňovská, Lucie. (2010). Customer Services-A Part of Market Orientation. Economics and Management, 15, 562-565. Retrieved from https://www.scribd.com/document/439986493/Customer-Services-a-Part-ofMarket-Orientation

Kaura, Vinita, Prasad, Ch. S. Durga, \& Sharma, S., (2015). Service Quality, Service Convenience, Price and Fairness, Customer Loyalty, and the Mediating Role of Customer Satisfaction. International Journal of Bank Marketing, 33(4), 404422. https://doi.org/10.1108/IJBM-04-2014-0048

Kotler, P. \& Amstrong, G. (2012). Principle of Marketing. $14^{\text {th }}$ Edition. New Jersey: Prentice Hall.

Kriswandari, S. (2011). Faktor-Faktor yang Mempengaruhi Kepuasan Konsumen Jasa Pendidikan pada STIE Lampung. Jurnal Manajemen dan Bisnis, 2(1), 1-15. Retrieved from http://jurnal.ubl.ac.id/index.php/jmb/article/view/45

Kriswandari, S. (2017). Pengaruh Kualitas Layanan Terhadap Kepuasan Pelanggan PT Astra Internasional Daihatsu Ahmad Yani Bandar Lampung. Ekombis Sains: Jurnal Ekonomi, Keuangan dan Bisnis, 2(2), 111-130. Retrieved from http://www.jurnal.saburai.ac.id/index.php/manajemen/article/view/287

Kuhn, V., et. al,. (2018). Food Services and Customer Loyalty in the Hospitality Industry. Tourism \& Management Studies, 14(2), 26-35. doi: 10.18089/tms.2018.14203

Kurniati, E., Silvia, E., \& Efendi, Z. (2016). Analisis Kepuasan Konsumen Terhadap Kue Baytat Bengkulu. Jurnal Teknologi dan Industri Pertanian Indonesia, 8(2), 67-75. https://doi.org/10.17969/jtipi.v8i2.6784

Malik, M. E., Ghafoor, M. M., \& Hafiz, K. I. (2012). Impact of Brand Image, Service Quality and Price on Customer Satisfaction in Pakistan Telecommunication Sector. International Journal of Business and Social Science, 3(23), 123-129. Retrieved http://www.ijbssnet.com/journals/Vol_3_No_23_December_2012/13.pdf

from

Malina, A. (2004). The Factor Analysis in Research of the Spatial Differentiation of Poland's Economic Structure. Statistics in Transition. 6(7), 1175-1188. Retrieved from https://www.emerald.com/insight/content/doi/10.1108/IJSE-082015-0198/full/xml

Martín-Consuegra, D., Molina, A., \& Esteban, Á. (2007). An Integrated Model of Price, Satisfaction and Loyalty: An Empirical Analysis in The Service Sector. Journal of Product \& Brand Management, 16(7), 459-468. https://doi.org/10.1108/10610420710834913

Matzler, K., Würtele, A. \& Renzl, B. (2006). Dimensions of Price Satisfaction: A Study in the Retail Banking Industry. International Journal of Bank Marketing, 24(4), 216-231. doi: 10.1108/02652320610671324

Nazari, M., Hosseini, M. A. S., \& Tabatabaie, V. (2014). Impact of Price Fairness on Price Satisfaction, Customer Satisfaction and Customer Loyalty in Iran Telecommunication Market (Case: MTN Irancell Company). Asian Journal of 
Vol. 5 No. 1 (2020)

ISSN (print): 2502-3918 | ISSN (online): 2502-7824

Research in Marketing, 3(1), 131-144. Retrieved from https://www.researchgate.net/publication/273452282_Impact_of_Price_fairness _on_Price_Satisfaction_Customer_satisfaction_and_Customer_Loyalty_in_Iran _Telecommunication_Market_Case_MTN_Irancell_Company

Oh, H. \& Kim, K. (2017). Customer satisfaction, Service Quality, and Customer Value: Years 2000-2015. International Journal of Contemporary Hospitality Management, 29(1), 2-29. doi: 10.1108/IJCHM-10-2015-0594

Osman, S., Fah, B., Chan. Y., \& Foon, Y. S. (2011). Simulation of Sales Promotions towards Buying Behavior among University Students. International Journal of Marketing Studies, 3(3), 78-82. doi:10.5539/ijms.v3n3p78

Park, M. \& Lennon, S. (2009). Brand Name and Promotion in Online Shopping Contexts. Journal of Fashion Marketing and Management: An International Journal, 13(2), 149-160. https://doi.org/10.1108/13612020910957680

Parsons, A. (2003). Assessing the Effectiveness of Shopping Mall Promotions: Customer Analysis. International Journal of Retail \& Distribution Management, 31(2), 74-79. https://doi.org/10.1108/09590550310461976

Qin, Hong, \& Prybutok, Victor R., (2009). Service Quality, Customer Satisfaction, and Behavioral Intentions in Fast-Food Restaurants. International Journal of Quality and Service Sciences, 1(1), 78-95. doi: 10.1108/17566690910945886

Rowley, J. (1998). Promotion and Marketing Communications in The Information $\begin{array}{llll}\text { Marketplace. } \quad \text { Library } & \text { 383-387. }\end{array}$ https://doi.org/10.1108/00242539810239543

Sachdev, S. B., \& Verma, H. V. (2004). Relative Importance of Service Quality Dimensions: A Multisectoral Study. Journal of Services Research, 4(1), 93-106. Retrieved from http://jsr-iimt.in/freesample/Relative.pdf

Santini, Fernando,. et, al,. (2015). An Analysis of the Influence of Discount Sales Promotion in Consumer Buying Intent and the Moderating Effects of Attractiveness. Revista de Administração, 50(4), 416-431. https://doi.org/10.5700/rausp1210

E. Schultz, D. \& P. Block, M. (2014). Sales Promotion Influencing Consumer Brand Preferences/Purchases. Journal of Consumer Marketing, 31(3), 212-217. https://doi.org/10.1108/JCM-01-2014-0822

Schultz, D. \& Peltier, J. (2013). Social Media's Slippery Slope: Challenges, Opportunities and Future Research Directions". Journal of Research in Interactive Marketing, 7(2), 86-99. https://doi.org/10.1108/JRIM-12-2012-0054

Sit, W., Ooi, K., Lin, B. \& Yee-Loong Chong, A. (2009). TQM and Customer Satisfaction in Malaysia's Service Sector. Industrial Management \& Data Systems, 109(7), 957-975. https://doi.org/10.1108/02635570910982300

Smith, M. \& Sinha, I. (2000). The Impact of Price and Extra Product Promotions on Store Reference. International Journal of Retail \& Distribution Management, 28(2), 83-92. https://doi.org/10.1108/09590550010315269

Graeff, T. (1995). Product Comprehension and Promotional Strategies. Journal of Consumer Marketing, 12(2), https://doi.org/10.1108/07363769510084885

28-39. 
Torres-Moraga, E., Vásquez-Parraga, A. \& Zamora-González, J. (2008). Customer Satisfaction and Loyalty: Start with the Product, Culminate with the Brand. Journal of Consumer Marketing, 25(5), 302-313. https://doi.org/10.1108/07363760810890534

Truong, Y. \& Rod McColl. (2011). Intrinsic Motivations, Self-Esteem, and Luxury Goods Consumption. Journal of Retailing and Consumer Services, 18, 555-561. Retrieved from https://www.sehity.com/uploads/4/2/2/4/42243697/truong_und_mccoll__2011_-_intrinsic_motivations,_self-esteem,_and_luxury_goo.pdf

Tsui-Hsu Tsai, T., Jing Lin, A. \& Y. Li, E. (2014). The Effect of Philanthropic Marketing on Brand Resonance and Consumer Satisfaction of CSR Performance: Does Media Self-Regulation Matter?. Chinese Management Studies, 8(3), 527-547. https://doi.org/10.1108/CMS-04-2014-0074

Walters, Rockney. G., \& Bommer, Wiliiam. (1996). Measuring the Impact of Product and Promotion-Related Factors on Product Category Price Elasticities. Journal of Business Research, 36(3), 203-216. https://doi.org/10.1016/01482963(95)00149-2 